\title{
Pengaruh Pemberian Biochar dan Pupuk Kandang terhadap Panjang Akar dan Jumlah Bintil Akar Tanaman Kacang Tanah (Arachis hypogaea L.)
}

The Effect of Biochar and Cow Manure Application on root length and root nodule of Peanut (Arachis hypogeae L.)

\author{
Andi Fahreza ${ }^{1}$, Zaitun ${ }^{1}$ dan Ainun Marliah ${ }^{1^{*}}$ \\ ${ }^{1}$ Program Studi Agroteknologi, Fakultas Pertanian, Universitas Syiah Kuala \\ *corresponding author :ainun.marliah@yahoo.com
}

\begin{abstract}
Abstrak. Kacang tanah menduduki urutan kedua tanaman kacang - kacangan setelah kedelai dalam segi ekonomi. Sehingga berpotensi untuk dikembangkan karena memiliki nilai ekonomi yang tinggi dan peluang pasar yang cukup besar. Namun, Ekstensifikasi lahan untuk tanaman pangan saat ini mengalami kendala karena terbatasnya lahan produktif. Usaha dalam menjaga ekstensifikasi lahan itu adalah dengan perluasan ke lahan kering. Penggunaan biochar dan pupuk kandang sebagai suatu pilihan dalam pengelolaan tanah untuk tujuan pemulihan dan peningkatan kualitas kesuburan tanah terdegradasi. Tujuan penelitian ini adalah untuk mengetahui pengaruh pemberian biochar dan pupuk kandang terhadap pertumbuhan dan hasil kacang tanah, serta interaksi antara keduanya terhadap pertumbuhan dan hasil kacang tanah. Penelitian ini telah dilaksanakan di kebun Campus Experimental Site The ACIAR Project Universitas Syiah Kuala, Darussalam, Banda Aceh. Penelitian telah dilaksanakan dari Mei sampai September 2017. Rancangan percobaan yang dilakukan dalam penelitian ini adalah rancangan acak kelompok (RAK) pola faktorial $3 \times 3$ dengan 3 ulangan. Hasil penelitian menunjukkan bahwa biochar berpengaruh nyata terhadap jumlah bintil akar. Hasil terbaik dijumpai pada pemberian biochar 5 ton ha $^{-1}$. Pemberian pupuk kandang berpengaruh nyata terhadap jumlah bintil akar. Hasil terbaik dijumpai pada pemberian pupuk kandang 2,5 ton $\mathrm{ha}^{-1}$.
\end{abstract}

Kata kunci : Kacang Tanah, Biochar dan Pupuk Kandang.

\begin{abstract}
Abstrack. Peanut has role as second-most productive soybean in economical aspect. Hence, it is potential to be developed and has high economic value and opportunity in agriculture. However, extensification of area for crops recently has prevention due to limited productive area. The way to effort the extensification is to expand the crops to the dry land area. Use of cow manure and biochar is solution in managing agricultural land area in order to recover and develop quality of degradated fertile soil. The purpose of study is to find out the affect and interaction between biochar and cow manure use toward growth and production of peanut. This research was conducted at Campus Experimental Site of ACIAR Project in Syiah Kuala University. The study was done from May to September in 2017. Experimental design used in this research was a randomized block design whose size was $3 \times 3$ factorial patterns with three repetitions. The study results that biochar influences the amount of nodules. The best finding of this study was on treatment of 5 ton ha ${ }^{-1}$ of biochar. In the other hand, the treatment of cow manure has influence on the amount of nodules. The best result of this context was found on treatment of 2,5 ton ha ${ }^{-1}$ of cow manure. Besides, there is interaction between biochar and cow manure treatment.
\end{abstract}

Keywords : Peanut, Biochar dan Cow Manure.

\section{PENDAHULUAN}

Kacang tanah (Arachis hypogaea L.) adalah komoditas tanaman pangan yang bisa dikonsumsi menjadi berbagai macam bahan makanan mulai dari disayur, direbus atau digoreng dan menjadi bahan baku untuk perindustrian seperti sabun, keju dan minyak. Kacang tanah menduduki urutan kedua tanaman kacang-kacangan setelah kedelai dalam segi ekonomi, sehingga apabila dikembangkan, akan memiliki nilai ekonomi yang tinggi dan peluang pasar yang cukup besar (Marzuki, 2007). 
Ekstensifikasi lahan untuk tanaman pangan saat ini mengalami kendala karena terbatasnya lahan produktif. Usaha dalam menjaga ekstensifikasi lahan itu adalah dengan perluasan ke lahan kering. Sistem pertanian lahan kering adalah praktek budidaya pertanian yang memiliki ketergantungan yang tinggi pada faktor iklim, sehingga mudah terdegradasi apabila pengelolaannya tidak tepat. Rendahnya kandungan unsur hara yang tersedia dan kandungan C-organik menyebabkan lahan kering memiliki tingkat kesuburan yang rendah. Perbaikan kesuburan tanah pada lahan kering dapat dilakukan dengan penambahan bahan organik, baik dengan pupuk kandang, kompos komersial dan sisa tanaman (Handayanto dan Ariesoesilaningsih, 2002).

Pupuk kandang adalah hasil samping yang terdiri atas kotoran padat dan cair dari hewan ternak yang telah bercampur dengan sisa makanan. Penggunaan pupuk kandang dalam budidaya pertanian mampu menambah unsur hara dan memperbaiki sifat fisik tanah. Beberapa sifat fisik tanah yang dapat diperbaiki oleh pupuk kandang yaitu bobot volume, kemantapan agregat, plastisitas, total ruang pori dan daya pegang air (Ariyanto, 2011).

Hasil penelitian menunjukkan bahwa pemberian pupuk kandang pada takaran 30 ton $\mathrm{ha}^{-1}$ mampu meningkatkan bobot biji kering pada tanaman kacang tanah mencapai 23,79 gram, sedangkan pada takaran 15 ton ha ${ }^{-1}$ hanya mencapai 18,12 gram (Hasanah, 2014). Penggunaan pupuk kandang sampai mencapai 30 ton $^{-1} a^{-1}$ tentunya belum efesien dalam budidaya pertanian. Sehingga diperlukan inovasi yang lebih aplikatif tanpa harus menggunakan pupuk kandang dengan dosis yang besar.

Biochar merupakan arang hitam hasil dari proses pemanasan biomassa pada keadaan oksigen terbatas atau tanpa oksigen. Penggunaan biochar sebagai suatu pilihan untuk pengelolaan lahan dan tanah dengan tujuan pemulihan dan peningkatan kualitas kesuburan tanah terdegradasi. Biochar juga merupakan bahan organik yang memiliki sifat stabil sehingga dapat digunakan sebagai pembenah tanah lahan kering (Tambunan et al. 2014).

Penggunaan biochar dan pupuk kandang dalam budidaya pertanian tentunya harus ditinjau lebih lanjut agar mendapatkan cara yang efektif dan aplikatif dalam meningkatkan hasil produksi sekaligus membantu perbaikan tanah. Oleh karena itu, dilakukan penelitian tentang pengaruh pemberian biochar dan pupuk kandang terhadap panjang akar dan bintil akar.

\section{METODE PENELITIAN}

\section{Tempat dan Waktu Penelitian}

Penelitian ini dilaksanakan di kebun Campus Experimental Site The ACIAR Project Universitas Syiah Kuala, Darussalam, Banda Aceh. Penelitian telah dilaksanakan dari Mei sampai dengan September 2017

\section{Alat dan Bahan Penelitian}

Alat-alat yang digunakan adalah alat pembuat biochar, ember, cangkul, meteran, timbangan, alat tulis, papan nama dan kamera digital. Sedangkan bahan yang digunakan adalah benih kacang tanah varietas F3 Bima sebanyak $2 \mathrm{~kg}$, biochar serbuk gergaji sebanyak $24,3 \mathrm{~kg}$, pupuk kandang sebanyak $24,3 \mathrm{~kg}$ dan pupuk urea sebanyak $0,486 \mathrm{~kg}$.

\section{Rancangan Penelitian}

Rancangan percobaan yang dilakukan dalam penelitian ini adalah rancangan acak kelompok (RAK) pola faktorial 3 × 3 dengan 3 ulangan. Adapun faktor yang diteliti yaitu dosis biochar dan dosis pupuk kandang dengan taraf masing-masing 0 ton ha ${ }^{-1}, 2,5$ ton ha ${ }^{-1}$ dan 5 ton $\mathrm{ha}^{-1}$. Dengan demikian terdapat 9 kombinasi perlakuan. Masing-masing perlakuan di ulang sebanyak 3 kali, sehingga penelitian mempunyai 27 satuan percobaan. 


\section{Prosedur Penelitian}

\section{Pembuatan Biochar}

Alat pembuat biochar merupakan modifikasi dari drum seng/kaleng dengan ukuran lebih kurang 200 liter. Serbuk gergaji dimasukkan kedalam drum sampai benar-benar padat kemudian dibakar dan langsung ditutup rapat. Kipas angin kemudian dihidupkan dan ditunggu selama 20-30 menit, biasanya ditandai dengan suhu pembakaran mencapai 400-600 ${ }^{\circ} \mathrm{C}$. Serbuk gergaji yang telah dibakar kemudian langsung disiram air sampai api benar-benar padam dan dikeringkan selama 2-3 hari.

\section{Pembuatan Bedengan}

Bedengan dibentuk dengan ukuran 1,2 $\mathrm{m}$ x $3 \mathrm{~m}$ dan tinggi bedengan $20 \mathrm{~cm}$ sebanyak 27 bedengan, jarak antar bedengan $50 \mathrm{~cm}$.

\section{Pengolahan tanah}

Tanah diolah dengan menggunakan cangkul, kemudian dibersihkan dari gulma dan digemburkan sampai bongkahan tanah menjadi halus. Pengolahan tanah dilakukan 2 minggu sebelum tanam.

\section{Penanaman}

Penanaman dilakukan dengan jarak tanam $30 \mathrm{~cm}$ x $30 \mathrm{~cm}$ dengan membuat lubang tanam kemudian memasukkan 3 benih perlubang tanam dan ditutupi dengan tanah. Pada umur 1 minggu setelah tanam dibuang 1 tanaman.

\section{Pengaplikasian Biochar dan Pemupukan}

Pupuk yang digunakan ialah pupuk kandang dan pupuk urea. Pupuk kandang diberikan 2 minggu sebelum penanaman. Kemudian diikuti dengan pemberian biochar. Dosis biochar dan pupuk kandang yang diberikan sesuai dengan perlakuan. Untuk pupuk urea yang digunakan adalah $1 / 4$ dari anjuran yaitu $50 \mathrm{~kg} \mathrm{ha}^{-1}$ dan diberikan saat penanaman. Pengaplikasian biochar dan pemumpukan diberikan dengan metode larikan di area lubang tanam.

\section{Pemeliharaan}

Pemeliharaan dilakukan dengan penyiangan. Penyiangan dilakukan dengan mengendalikan gulma yang ada di sekitar areal pertanaman. Dalam pemeliharan juga dilakukan pembumbunan agar tanahnya gembur. Penyiraman dilakukan dua kali sehari dengan gembor yaitu pagi dan sore hari kecuali apabila turun hujan tidak dilakukan penyiraman.

\section{Pemanenan}

Pemanenan kacang tanah 100 hari setelah tanam dengan kriteria 75\% daun sudah menguning dan polong sudah berwarna coklat, keras dan bila dibuka biji telah terisi penuh.

\section{Parameter Pengamatan}

Parameter yang diamati adalah panjang akar dan jumlah bintil akar.

\section{Analisis Data Penelitian}

Data hasil pengamatan pada setiap parameter dianalisis dengan anova. Data yang menunjukkan perbedaan yang nyata pada Fhitung maka dilanjutkan dengan Uji Beda Nyata Jujur (BNJ) pada taraf 0,05 . 


\section{HASIL DAN PEMBAHASAN}

\section{Pengaruh Pemberian Biochar terhadap Panjang Akar dan Jumlah Bintil Akar}

Hasil uji $\mathrm{F}$ analisis ragam menunjukkan bahwa pemberian biochar berpengaruh nyata terhadap jumlah bintil akar. Jumlah bintil akar akibat pemberian biochar lebih banyak dijumpai pada pemberian biochar 5 ton ha $^{-1}\left(\mathrm{~B}_{2}\right)$ yang berbeda nyata dengan jumlah bintil akar akibat pemberian biochar 0 ton ha $^{-1}\left(\mathrm{~B}_{0}\right)$ namun berbeda tidak nyata jumlah bintil akar akibat pemberian biochar 2,5 ton $\mathrm{ha}^{-1}\left(\mathrm{~B}_{1}\right)$. Selanjutnya, pada panjang akar akibat pemberian biochar cenderung lebih panjang dijumpai pada pemberian biochar 5 ton $\mathrm{ha}^{-1}\left(\mathrm{~B}_{2}\right)$, walaupun secara statistik berbeda tidak nyata dengan panjang akar akibat pemberian biochar 0 ton ha ${ }^{-1}$ $\left(\mathrm{B}_{0}\right)$ dan 2,5 ton ha ${ }^{-1}\left(\mathrm{~B}_{1}\right)$.

Hasil penelitian menunjukkan bahwa jumlah bintil akar kacang tanah terbaik di jumpai pada pemberian biochar 5 ton ha ${ }^{-1}$. Hal ini diduga karena fungsi biochar sebagai pembenah tanah dan mampu merangsang pertumbuhan dan perkembangan akar. Blanco et al., 2014 menyatakan bahwa pemberian biochar pada tanah kritis mampu meningkatkan kesuburan tanah dan perkembangan akar karena biochar mempunyai kemampuan untuk memperbaiki sirkulasi air dan udara di dalam tanah. Sesuai dengan pernyataan Berek (2017) bahwa pemberian biochar mampu memperbaiki kapasitas tanah merentensi air dan struktur tanah, sehingga akar tanaman lebih mudah berkembang di dalam tanah. Biochar juga mampu memperbaiki aerasi dan porositas tanah sehingga respirasi akar dan kehidupan mikroba bermanfaat lainnya lebih tinggi (ditunjukkan dengan jumlah bintil akar meningkat).

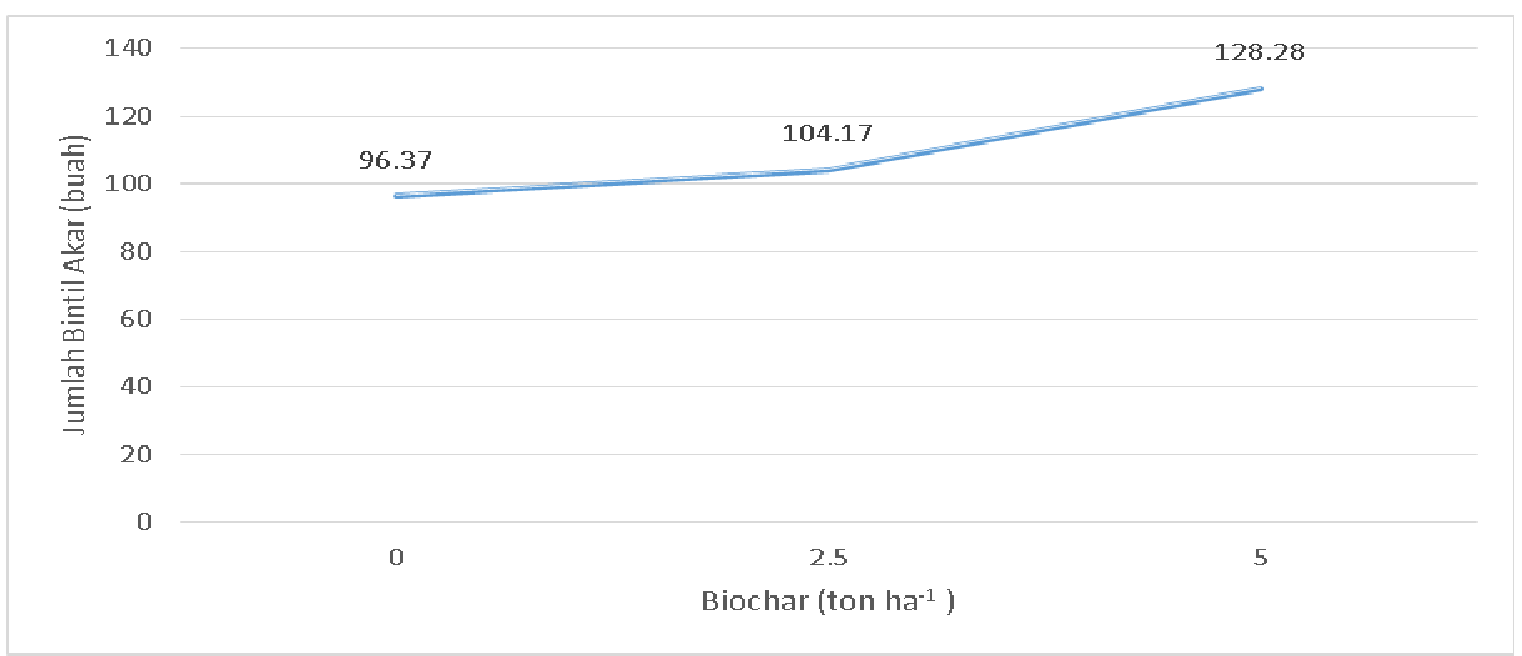

Gambar 1. Rata-rata jumlah bintil akar tanaman kacang tanah akibat pemberian biochar

Tabel 1. Rata-rata panjang akar dan jumlah bintil akar kacang tanah akibat pemberian biochar

\begin{tabular}{lcccc}
\hline \multirow{2}{*}{ Parameter yang diamati } & \multicolumn{3}{c}{ Biochar ton ha $\mathrm{ha}^{-1}$} & BNJ \\
\cline { 2 - 4 } & $0\left(\mathrm{~B}_{0}\right)$ & $2,5\left(\mathrm{~B}_{1}\right)$ & $5\left(\mathrm{~B}_{2}\right)$ & 0,05 \\
\hline Panjang akar $(\mathrm{cm})$ & 18,48 & 18,69 & 18,49 & - \\
Jumlah bintil akar (buah) & $96,37 \mathrm{a}$ & $104,17 \mathrm{ab}$ & $128,28 \mathrm{~b}$ & 25,80
\end{tabular}

Keterangan : Angka yang diikuti oleh huruf yang sama pada baris yang sama berbeda tidak nyata pada taraf $5 \%\left(\mathrm{Uji}_{\mathrm{BNJ}} \mathrm{B}_{05}\right)$

Pemberian biochar berpengaruh tidak nyata terhadap panjang akar. Hal ini diduga biochar membutuhkan waktu yang lama untuk berpengaruh terhadap panjang akar. Penelitian Samira 
(2012) menunjukkan bahwa penanaman kedua pada lahan dengan pemberian biochar 10 ton $\mathrm{ha}^{-1}$ berpengaruh nyata terhadap potensi hasil padi dengan kadar air 14\% mencapai 5,8 ton ha 1 . Biochar yang sudah berumur cukup lama memiliki Kapasitas Tukar Kation (KTK) yang tinggi dan mempunyai sifat absorpsi yang lebih besar terhadap kation melalui oksidasi permukaan dibanding melalui absorpsi oleh bahan organik biasa (Cheng et al. 2007).

\section{Pengaruh Pemberian Pupuk Kandang terhadap Pertumbuhan dan Hasil Kacang Tanah}

Hasil uji $\mathrm{F}$ pada analisis ragam menunjukkan bahwa pemberian pupuk kandang berpengaruh nyata pada jumlah bintil akar. Jumlah bintil akar akibat pemberian pupuk kandang lebih banyak dijumpai pada pemberian pupuk kandang 2,5 ton $\mathrm{ha}^{-1}$ ( $\mathrm{K}_{1}$ ) yang berbeda nyata dengan jumlah bintil akar akibat pemberian pupuk kandang 5 ton ha ${ }^{-1}\left(\mathrm{~K}_{2}\right)$ namun berbeda tidak nyata dengan jumlah bintil akar akibat pemberian pupuk kandang 0 ton $\mathrm{ha}^{-1}\left(\mathrm{~K}_{0}\right)$. Pada panjang akar akibat pemberian pupuk kandang cenderung lebih panjang dijumpai pada pemberian pupuk kandang 0 ton $\mathrm{ha}^{-1}\left(\mathrm{~K}_{0}\right)$, walaupun secara statistik berbeda tidak nyata dengan panjang akar akibat pemberian pupuk kandang 0 ton $\mathrm{ha}^{-1}\left(\mathrm{~K}_{0}\right)$ dan 5 ton $\mathrm{ha}^{-1}\left(\mathrm{~K}_{2}\right)$.

Pemberian pupuk kandang berpengaruh nyata terhadap jumlah bintil akar. Hal ini diduga karena pupuk kandang mampu meningkatkan kadar humus dan unsur hara dalam tanah. Hartatik (2006) menjelaskan bahwa pupuk kandang adalah sumber beberapa hara seperti nitrogen, fosfor, kalium dan lainnya. Nitrogen menjadi salah satu hara utama bagi tanaman dan dapat diperoleh dari pupuk kandang. Sebelum nitrogen diserap oleh tanaman, nitrogen dirubah menjadi nitrat tersedia. Selain itu, pupuk kandang juga mendorong proses penggemburan tanah, sehingga dapat menunjang pertumbuhan dan perkembangan tanaman. Hasil penguraian senyawa kompleks seperti polisakarida dari pupuk kandang dapat mengikat partikel-partikel tanah ke dalam unit-unit agregat yang porous sehingga memudahkan infiltrasi dan perkolasi. Kondisi ini meningkatkan pasokan oksigen untuk respirasi serta pertumbuhan akar karena pertukaran gas menjadi lebih baik (Stevenson, 1982). Penelitian Latarang (2006) menunjukkan bahwa pemberian pupuk kandang pada tanaman bawang berpengaruh sangat nyata terhadap jumlah umbi dan Bobot umbi perumpun. Penelitian Barus (2012) menunjukkan pemberian pupuk kandang mampu meningkatkan jumlah anakan dan jumlah gabah pada padi gogo. 


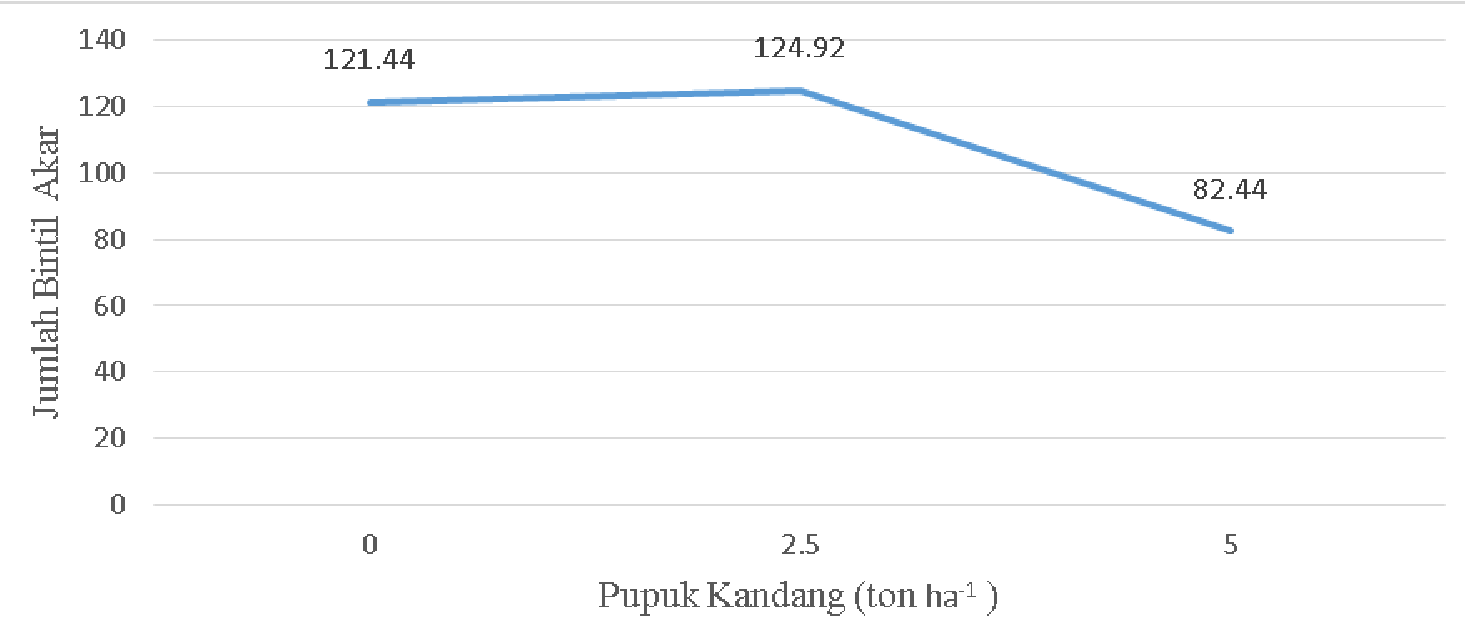

Gambar 2. Rata-rata jumlah bintil akar tanaman kacang tanah akibat pemberian pupuk kandang

Tabel 2. Rata-rata panjang akar dan jumlah bintil akar kacang tanah akibat pemberian pupuk kandang

\begin{tabular}{lcccc}
\hline \multirow{2}{*}{ Parameter yang diamati } & \multicolumn{3}{c}{ Biochar ton ha $^{-1}$} & BNJ \\
\cline { 2 - 4 } & $0\left(\mathrm{~B}_{0}\right)$ & $2,5\left(\mathrm{~B}_{1}\right)$ & $5\left(\mathrm{~B}_{2}\right)$ & 0,05 \\
\hline Panjang akar $(\mathrm{cm})$ & 19,37 & 17,66 & 18,63 & - \\
Jumlah bintil akar (buah) & $121,44 \mathrm{~b}$ & $124,92 \mathrm{~b}$ & $82,44 \mathrm{a}$ & 33,89
\end{tabular}

Keterangan : Angka yang diikuti oleh huruf yang sama pada baris yang sama berbeda tidak nyata pada taraf $5 \%\left(\mathrm{Uji}_{\mathrm{BNJ}} 0,05\right)$

Pemberian pupuk kandang berpengaruh tidak nyata terhadap panjang akar. Hal ini diduga karena pupuk kandang lebih dominan memperbaiki struktur tanah. Pupuk kandang mampu meningkatkan agregat tanah, aerasi dan daya menahan air sehingga menjadikan penyerapan hara semakin luas (Indria, 2005). Namun, lahan yang digunakan merupakan lahan yang memiliki kandungan unsur hara yang beragam dan cenderung rendah (berdasarkan Tabel 1. Sifat kimia tanah Campus Experimental Site The Project ACIAR Universitas Syiah Kuala), sehingga pupuk kandang belum mampu memaksimalkan ketersedian hara dan penyerapan unsur hara.

\section{Interaksi Pemberian Biochar dengan Pupuk Kandang Terhadap Pertumbuhan dan Hasil Tanaman Kacang Tanah}

Hasil uji $\mathrm{F}$ analisis ragam menunjukkan bahwa tidak terdapat interaksi antara pemberian biochar dan pupuk kandang terhadap panjang akar dan jumlah bintil akar.

\section{KESIMPULAN}

Pemberian biochar berpengaruh nyata terhadap jumlah bintil akar. Pemberian biochar yang terbaik dijumpai pada pemberian biochar 5 ton $\mathrm{ha}^{-1}$. Pemberian pupuk kandang berpengaruh nyata terhadap jumlah bintil akar. Pemberian pupuk kandang terbaik dijumpai pada pemberian pupuk kandang 2,5 ton $\mathrm{ha}^{-1}$. 


\section{DAFTAR PUSTAKA}

Arianto, S. 2011. Perbaikan Kualitas Pupuk Kandang Sapi dan Aplikasinya Terhadap Tanaman Jagung Manis (Zea mays Saccharata Sturt), Jurnal Fakultas Pertanian Universitas Muria Kudus. 4 (2): 164-175.

Ariesoesilaningsih, E., Sulvijayanti, E.D., Mastuti, R., Nuriyah, L. Maftu'ah, E. and Pratikno, H. 2001. Seleksi diversitas tumbuhan C3 dan C4 energetik dan nutritif di lahan kritis berkapur DAS Brantas. Makalah Seminar Nasional Biologi 2.29 Agustus 2001. Fakultas MIPA. Institut Teknologi Sepuluh November. Surabaya

Barus, J. 2012. Pengaruh aplikasi pupuk kandang dan sistim tanam terhadap hasil dan varietas unggul padi gogo pada lahan kering masam di Lampung.. Jurnal Lahan Suboptimal. 1 (1): 102-106.

Berek., A. K. et al. 2017. Perbaikan pertumbuhan dan hasil kacang tanah di tanah entisol semiarid melalui aplikasi biochar. Portal Jurnal Unimor. 2(3): 56-58. Fakultas Pertanian. Universitas Timor. Kefamenaru.

Blanco., H. Canqui, and R. Lal. 2004. Mechanisms of carbon sequestration in soil agre gates. Cri. Rev. in Palnt SCI. 23(6): 481-504.

Cheng C.H., J. Lehmann, J.E. Thies, S.D. Burton, and M.H. Engelhard. 2007. Oxidation of black carbon by biotic and abiotic processes. Organic Geochemistry. 37:1477-1488.

Endriani. 2013. Pemanfaatan biochar cangkang kelapa sawit sebagai soil amandement ultisol sungai bahar. Jambi. Fakultas Pertanian Universitas Jambi. 15(1): 39 - $46 .$.

Hartatik, W., Widowati, R. L. 2006. Pupuk kandang. balittanah.litbang.deptan.go.id Diakses tanggal :10 Oktober 2017.

Hasanah, K.S., Fitria, S.B. dan Fitriah, S.Y. 2014. Pengaruh pemberian pupuk organik terhadap pertumbuhan dan hasil kacang tanah (Arachis hypogeae L.) varietas bima dan varietas jerapah. Fakultas Pertanian Universitas Negeri Gorontalo. Gorontalo.

Indria, A. T. 2005. Pengaruh sistem pengolahan lahan dan pemberian macam organik terhadap pertumbuhan dan hasil kacang tanah (Arachis hypogaea L.). Skripsi S1

Fakultas Pertanian Universitas Sebelas Maret. Surakarta.

Latarang, B. dan A. Syakur. 2006. Pertumbuhan dan hasil bawang merah (Allium alcolonium L.) pada berbagai dosis pupuk kandang. Jurnal Agroland. 13(3): $256-269$.

Marzuki, H.A.R. 2007. Bertanam kacang tanah. Edisi revisi. Penebar Swadaya. Jakarta.

Samira, D. 2012. Pengaruh residu biochar dan pupuk NPK terhadap sifat kimia tanah dan hasil padi sawah irigasi. Thesis Magister. Program Pascasarjana Universitas Syiah Kuala, Darussalam, Banda Aceh.

Stevenson, F.T. 1982. Humus Chemistry. Jhon Wiley and Sons. Newyork.

Tambunan, et al. 2014. Pengaruh aplikasi bahan organik segar dan biochar terhadap ketersediaan $\mathrm{p}$ dalam tanah di lahan kering malang selatan. Fakultas Pertanian.

Unversitas Brawijaya. Malang. 